\title{
PERCEPTIONS AND EXPECTATIONS ON FOREST MANAGEMENT CERTIFICATION OF FORESTERS IN STATE FOREST ENTERPRISES: A CASE STUDY IN TURKEY
}

\author{
ŞEN, G.* - GENÇ, A. \\ Faculty of Forestry, Kastamonu University \\ 37200 Kastamonu, Turkey \\ (phone: +90-532-562-5998; fax: +90-366-215-2316) \\ *Corresponding author \\ e-mail: gsen@kastamonu.edu.tr; phone: +90-532-562-5998; fax: +90-366-215-2316 \\ (Received $6^{\text {th }}$ Sep 2017; accepted $15^{\text {th }}$ Jan 2018)
}

\begin{abstract}
Determination of the perception of employees in the forestry organization involved in forest management certification (FMC) in state forests is considered important in increasing the success level of this process. In this study, some questions were asked to evaluate the opinions of the forest management directorate employees [forest engineers (FE), rangers (R), and forest workers (FW)] about the forest management certificate and to know the expectations about certification. Data has been collected by conducting face-to-face interviews with $51 \mathrm{FEs}, 56 \mathrm{Rs}$, and $80 \mathrm{FWs}$. This data collection was done at the certified forest enterprise of the Kastamonu Regional Directorate of Forestry, which has been selected as the work area. The research methods included descriptive statistics, one-way analysis of variance, and correspondence analysis for hypothesis testing. When a statistical significance $(p=0.05)$ was found, the intergroup differences were analyzed using a post hoc test. Our results showed differences in the perceptions of foresters, with $90 \%$ of FEs, Rs, and FWs stating that the certification process contributes positively to forest management. Moreover, $35.8 \%$ of the foresters stated that FMC encouraged selection of the most suitable forest management, $34.5 \%$ stated that FMC ensured forest management according to sustainable forest management (SFM) criteria and in compliance with international agreements, and $30.1 \%$ stated that FMC contributed to the conservation and survival of forest areas.
\end{abstract}

Keywords: sustainability, sustainable forest management, forest management certification, Forest Stewardship Council certification, Turkey

\section{Introduction}

Although forests have been considered as firewood and timber supply areas until very recently, forest and related ecosystems have important roles as sources of food, round wood, firewood, water, fresh air, fossil fuels, shelter and are important in climate regulation, flood protection, disease control, water conservation, all of which support human life (Tolunay and Başsüllü, 2015; Krieger, 2001). However, despite all these unique qualities, human beings continue to destroy forests due to negligent consumptive behaviour. Specifically, as a result of excessive use, $60 \%$ of the functions of the forests have been impaired or jeopardized in terms of sustainability worldwide (Brockhouse and Botoni, 2009). Therefore, activities to manage existing forests in an orderly manner and establish new forest areas have gained importance (Eler, 2010).

Although degradation and destructions in the world's forests continue, programs to halt this trend, such as the tropical Forestry Action Plans, the International Tropical Timber Agreement, the Convention on the International Trade in Endangered Species of Flora and Fauna (CITES), and the Global Environment Facility, have not been fully effective in addressing forest degradation and destruction. This shortcoming was especially pronounced at the Earth Summit in Rio de Janeiro in 1992. In addition to 
many governments, many non-governmental organizations have also pressed for overcoming these deficiencies. As a result, although no legally binding commitments were made, the Agenda 21 Forestry Principles set out an action plan to delve into sustainable forestry issues (Asan, 2010; Durusoy, 2002; Pfeifer, 2003).

Although regional processes around the world have their distinct characteristics, seven important points are common in all processes, and these are listed as SFM criteria: (1) size of forest resources; (2) biodiversity in forests; (3) health and vitality of forests; (4) protection functions of forests; (5) production functions of forests; (6) socioeconomic functions of forests, (7) legal, political and institutional frameworks (CICI, 2003).

While processes of developing criteria for SFM continue, forest certification has begun to take shape through non-governmental organizations (Perera and Vlosky, 2006). The forest certification system is the most important concept that nongovernmental organizations have developed to achieve SFM. This concept has been developed for certifying and labelling forests and forest products, and forest certification emerged in the $1990 \mathrm{~s}$ as an instrument to facilitate sustainable use of natural resources (Cubbage et al., 2007). As a result, certification efforts were initiated by a voluntary non-profit organization called the Forest Stewardship Council (FSC), 1993 World Wide Fund for Nature (WWF) coalition, and other leading environmental organizations (Perera and Vlosky, 2006; Rametsteiner, 2002). Today, there are many organizations that perform certification, including Canadian Standards Association SFM System (CSA), Malaysian Timber Certification Council, Programme for the Endorsement of Forest Certification (PEFC), CERTFOR, Australian Forestry Standard (AFS) etc. (Klingberg, 2003; Ozinga, 2008; Eryllmaz and Tolunay, 2015). Although certification processes initially focused on tropical forests, they were expanded to cover continental forests and temperate forests (Perera and Vlosky, 2006; Nussbaum and Simula, 2005).

Approximately $8 \%$ of the world's forests are certified. The highest share in this certification processes belongs to PEFC and FSC (Y1ldırım, 2010). FSC Principles and Criteria for Forest Stewardship are used as the basis for independent, third-party certification of forest management operations around the world. FSC principles and criteria are used as the basis for independent, third-party certification of forest management operations around the world. FSC has certified 194,478,017 hectares of forests across the world with a total of 1519 certificates in 84 countries (FSC, 2017).

Especially in recent years, many studies have been conducted to determine perceptions of stakeholders about forest certification (Bass et al., 2001; Cashore et al., 2002; Carrera et al., 2004; Pinto and McDermott, 2013; Trishkina et al., 2014; Pratiwi et al., 2015). Some studies in this field have been conducted in Turkey (Durusoy, 2002; Akyol and Tolunay, 2006; Tolunay and Türkoğlu, 2014; Ayan et al., 2009; Şenöz, 2014); however, a study that evaluates every aspect of forest management certification (FMC), especially one questioning the views and opinions of the stakeholders, has not been reported yet.

Decisions taken in the process of certification of forests in Turkey have been made within the framework of a top-down hierarchy. Forest certification studies in Turkey have started with the studies that the General Directorate of Forestry has initiated in line with the requests of Turkish companies wanting to export wood-based products to Europe. In this context, no preliminary studies or assessments have been made that involved participation of all stakeholders. The perceptions of employees of the forestry 
organization on certification itself are important for obtaining certification and maintained it. To what extent will it be possible to achieve success and to maintain these activities with staff are not convinced about the certification process and its positive effects on forestry? For this reason, it is very important to determine the opinions of the employees in the forestry organization who will directly implement certification process. The results obtained will help decision makers on what needs to be done before certification processes take place in the future.

Forest assets in Turkey are 22.3 million hectares, accounting for $28.6 \%$ of the total area of the country. Approximately 57\% of this area consists of productive forest areas (GDF, 2016), and 99\% of the forests in Turkey are owned by the state. Turkey's total industrial wood production is $7,895,000 \mathrm{~m}^{3}$, and total firewood production is $8,408,400 \mathrm{~m}^{3}$. In the last decade, an annual average of 13 million $\mathrm{m}^{3}$ of industrial wood was supplied, as well as 1.5 million $\mathrm{m}^{3} /$ year of wood raw material was imported (KRDF, 2016).

The first management plan for forests in Turkey was prepared in 1963 (Eler, 2010). The General Directorate of Forestry (GDF), which is the organization that operates and manages forest assets in Turkey, has the following aims: (i) to protect, develop, and expand forests; (ii) to provide society with sustainable multiple benefits from forest resources, (iii) to improve capacity of the institution to realize these services faster and better; and (iv) operation and management of forest areas with these aims within a sustainability framework (GDF, 2012). In this context, Turkey has been in sync with the developments around the world, and has participated in pan-Europe and FAO-UNEP Near East processes.

The certification studies, which have made significant improvements in the last twenty years in the world, were initiated in 2010 in Turkey. Although Turkey has been involved in this process only for a short duration, approximately $10 \%$ of Turkey's forests have been included in the scope of certification program. All FMC studies that were conducted in Turkey were executed by the FSC. By year of 2015, FMC has been performed for 3,249,999 hectares forest area in Turkey and this figure is expected to be 5 million hectares in 2019 (Şen et al., 2013; Şenöz, 2014).

In this study, the perceptions and expectations of forestry organization employees in state forest regarding FMC were evaluated. In addition, expectations of the forestry groups about possible developments that may take place after FMC and differences between the groups in terms of their expectations were also revealed. In a country like Turkey, where forests are almost entirely state-owned, revealing the points of view and expectations of forestry organization about forest certification is expected to contribute both to the success of certification efforts as well as its sustainability and help decision makers in the other similar countries on the pre-certification procedures. Determination of the differences in opinion of foresters groups on FMC will contribute to and assist decision makers and relevant stakeholders in the new regulations to be made regarding the tasks of these groups with different job descriptions as well as in the plans to be made. In addition to these, the results of the study will be helpful in formulating national forest certification criteria and in the identifying forestry policy objectives. Additionally, comparisons between the FMC applications adopted in private forests and state forests can be performed and relevant evaluations can be conducted. 


\section{Materials and methods}

\section{Description of the research site}

This study was carried out conducted in Kastamonu Regional Directorate of Forestry (KRDF). KRDF is ranked first for total wood wealth and total wood sales volume in 27 Regional Directorates of Forestry in Turkey. The certified forest areas in KRDF constitute $20.8 \%$ of the total certified forest areas in Turkey (Şen et al., 2013; Güneş Şen, 2015). KRDF is located approximately between the $41^{\text {st }}-42^{\text {nd }}$ northern parallels and the $33^{\text {rd }}-35^{\text {th }}$ eastern meridians. KRDF is located in the West Black Sea Region of Turkey and includes Sinop and Kastamonu provinces within its borders (Fig. 1). There are a total of 1542 villages in the area, most of which are forest villages (1488). The total population in the study area is 576,766 (TSI, 2016). Approximately 245,586 of these individuals are forest villagers (living in villages located in the forest or at the edges of the forest) (KRDF, 2016). Two national parks are included in the study areaKüre Mountains National Park and Ilgaz Mountain National Park with Protected Areas Network (PAN) park certification (Anonymous, 2014; Öztürk and Ayan, 2015). Moreover, Küre Mountains are home to five distinct habitat types categorized as endangered habitats as per the Convention on the Conservation of European Wildlife and Habitats (Bern Convention) (LTDP, 2008). KRDF operates approximately 1.2 million hectares of forest area on a 2 million hectares area via 21 Forestry Enterprise Directorates (FED) within its body (Şen et al., 2013). Among these forest enterprises, Daday, Araç, Ayancık, Taşköprü, and Tosya FEDs have received FMC according to the FSC standards (Fig. 1).

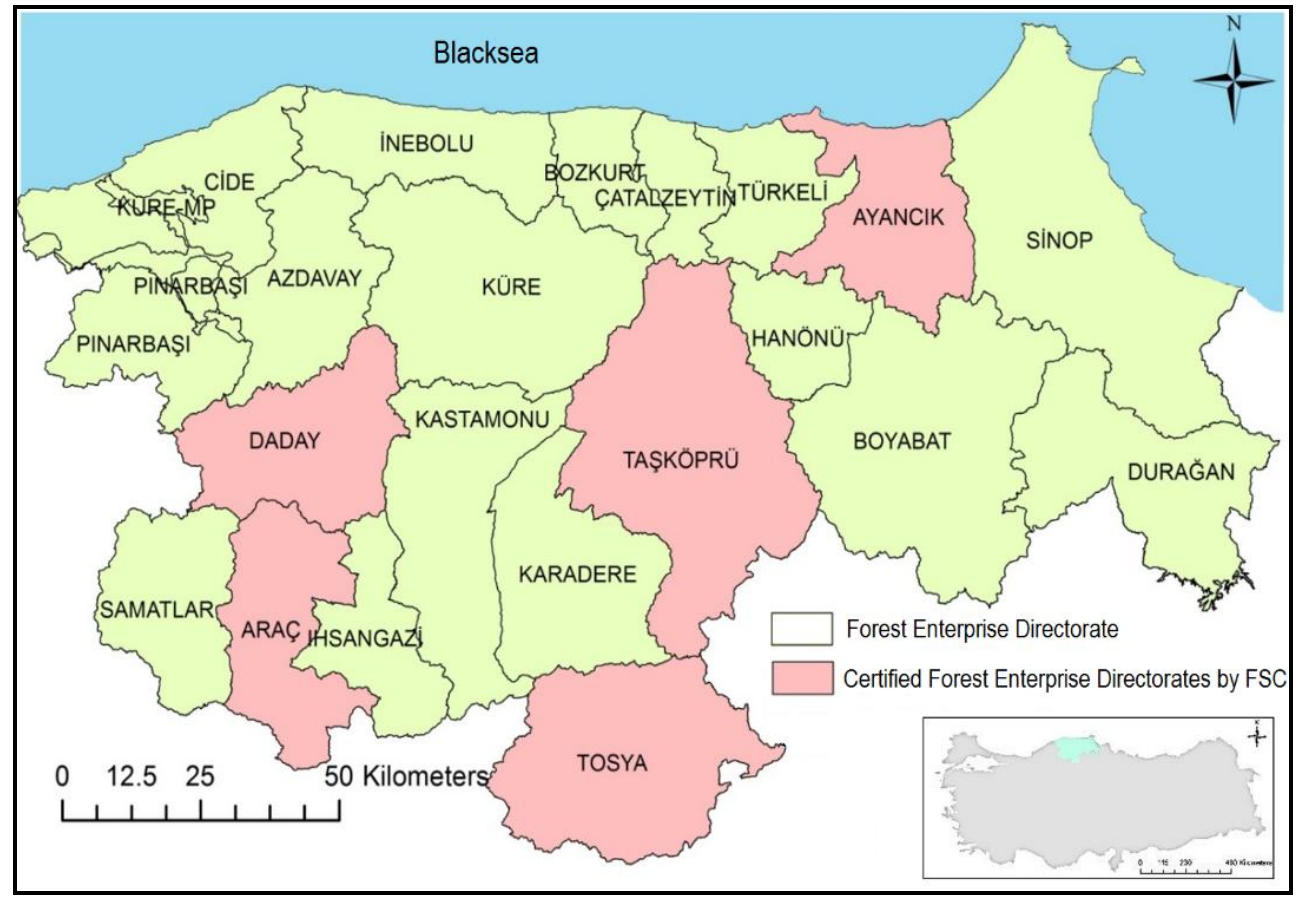

Figure 1. Locations of KRDF and certified FEDs

Distribution of forest lands of KRDF and certified FEDs are shown in Table 1 (KRDF, 2014). 
Table 1. Distribution of forest land (ha)

\begin{tabular}{|c|c|c|c|c|c|c|}
\hline \multirow{2}{*}{ FED } & \multicolumn{2}{|c|}{ High forest (ha) } & \multicolumn{2}{|c|}{ Coppice (ha) } & \multirow{2}{*}{$\begin{array}{c}\text { Forested land } \\
\text { (ha) }\end{array}$} & \multirow{2}{*}{$\begin{array}{c}\text { General land } \\
\text { (ha) }\end{array}$} \\
\hline & Productive & Degraded & Productive & Degraded & & \\
\hline Daday & 52422.9 & 11444.9 & - & & 63867.8 & 85465.6 \\
\hline Vehicle & 35264.0 & 11258.0 & - & 4102.0 & 50624.0 & 76062.0 \\
\hline Ayancık & 54189.0 & 4869.0 & - & & 59058.0 & 80195.3 \\
\hline Taşköprü & 82469.5 & 31049.4 & - & & 113518.9 & 176647.9 \\
\hline Tosya & 55499.3 & 24807.1 & - & & 80306.4 & 122636.1 \\
\hline $\begin{array}{l}\text { Certified } \\
\text { FED }\end{array}$ & 279844.7 & 83428.4 & - & 4102.0 & 367375.1 & 541006.9 \\
\hline KRDF & 930357.1 & 285885.9 & 8570.5 & 25778.1 & 1250591.6 & 2011116.2 \\
\hline
\end{tabular}

As shown in Table 1, the total area of five FEDs included in KRDF is 541,006.9 ha, which constitutes $26.9 \%$ of total KRDF area and $29.38 \%$ of forest lands. Approximately $30 \%$ of productive high forests and $29 \%$ of degraded high forests of KRDF were certified. $29 \%$ of total forest lands have FMC.

\section{Identification of target groups of the study}

Because $99.9 \%$ of the forests in Turkey are state-owned, a successful certification process is directly proportional to the selfless work of the employees. Most of the current employees are permanent staff. Their salary does not depend on their work performance. In this context, a new system to be brought to forestry can mean disruption of conventional order and added workload for most of the employees. Therefore, evaluating the level of awareness of the foresters engaged in land and office work during the certification process, their thoughts on certification, and their expectations from certification is important for the establishment of forestry policies. In this context, a survey was conducted with forestry groups directly working in FMC tasks. Therefore, in this study, we collected original data from the surveys conducted for forest engineers (FE), rangers (R) and forest workers (FW) staff of forestry organizations. Employees working in Daday, Araç, Ayancık, Taşköprü, and Tosya FEDs, which have received FSC from KRDF, participated in the surveys. Moreover, the results of previous studies and the KRDF documents were used.

In this study, participants are divided into three groups. FEs are employees with a 4year undergraduate degree in forest management and working as engineers or managers. Rs are employees with a 2-year associate degree in forest management and are employed in forest protection duties of enterprises and other related tasks. FW's are high-school graduates or represent/have lower educational level and are generally employed in heavy jobs such as production and fire extinguishing. Most FWs are villagers living near or in forests. Identification of differences between the groups will help to improve foresters' trust in and internalization of the work as well as awareness about the work, which are important factors in the success of certification process.

According to KRDF data, there are $55 \mathrm{FE}, 102 \mathrm{R}$, and $313 \mathrm{FW}$ working in FED's which were certified. The following formula (Eq. 1) was used for determining the sample size (Serper, 2000; Orhunbilge, 2000): 


$$
\mathrm{n}=\frac{\mathrm{N} * \mathrm{t}^{2} * \mathrm{P} * \mathrm{Q}}{\left(\mathrm{d}^{2}(\mathrm{~N}-1)\right)+\left(\mathrm{t}^{2} * \mathrm{P} * \mathrm{Q}\right)}
$$

The various parameters in this equation are as follows- $\mathrm{n}$ : sample size; $\mathrm{t}^{2}$ : confidence level 90\% (1.64); N: Population (55 FE; 102 R; 313 FW); P: probability of the presence of the aspect aimed to be measured within the main group (taken $50 \%$ because of the multipurpose nature of this study); Q: $1-\mathrm{P}$; d: Sampling error considered $10 \%(0.1)$. Thus it was calculated that: $\mathrm{n}=35 \mathrm{FE} ; 50 \mathrm{R} ; 74 \mathrm{FW}$

To increase the survey reliability level, $50 \mathrm{FE} ; 57 \mathrm{R}$; $80 \mathrm{FW}$ foresters instead of 35 FE; $50 \mathrm{R} ; 74 \mathrm{FW}$ were interviewed. Participants for surveying were selected by random sampling method. The main mass and sample sizes according to the enterprise directorates are shown in Table 2.

Table 2. Sample sizes and number of survey participants

\begin{tabular}{c|c|c|c}
\hline FDD & Number of engineers & Number of officers & Number of workers \\
\hline Daday & 9 & 19 & 68 \\
Vehicle & 6 & 14 & 42 \\
Ayancık & 17 & 20 & 52 \\
Taşköprü & 14 & 28 & 97 \\
Tosya & 9 & 21 & 54 \\
\hline Total & 55 & 102 & 313 \\
\hline Sample sizes & 35 & 50 & 74 \\
\hline Survey participants & 50 & 57 & 80 \\
\hline
\end{tabular}

Table 3 shows the general demographics of the foresters according to their age, level of education, and gender.

Table 3. Education, work position, and age of the foresters

\begin{tabular}{|c|c|c|c|c|c|c|c|c|c|c|c|c|c|c|c|}
\hline & Age groups (years & & & & -30 & & & & -50 & & $1-60$ & & $<<$ & $T$ & 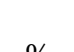 \\
\hline & Gender & & & $\mathrm{F}$ & M & $\mathrm{F}$ & M & $\mathrm{F}$ & M & $\mathrm{F}$ & $\mathrm{M}$ & $\mathrm{F}$ & M & & \\
\hline & Primary education & & FW & - & 3 & - & 5 & - & 36 & - & 16 & - & - & 60 & $\begin{array}{r}32.1 \\
64\end{array}$ \\
\hline & & & FW & - & 3 & - & 4 & - & 7 & - & & - & - & 14 & 75 \\
\hline$\vec{j}_{0}^{0}$ & High school & ๘ & $\mathrm{R}$ & - & - & - & 3 & _ & 18 & - & 5 & - & - & 26 & 13.9 \\
\hline$\overline{\tilde{\sigma}}$ & & 5 & FW & 2 & 2 & - & - & - & 1 & - & - & - & - & 5 & 2.7 \\
\hline 䔍 & Undergraduate degree & $\stackrel{2}{\beth}$ & $\mathrm{R}$ & 1 & 5 & - & 1 & 2 & 5 & - & - & - & 1 & 15 & 8.0 \\
\hline 可 & & $\dot{3}^{\circ}$ & FW & - & - & - & 1 & - & - & - & - & - & - & 1 & 0.5 \\
\hline & Bachelor's degree & & $\mathrm{R}$ & - & 3 & 1 & 1 & - & - & - & - & - & - & 5 & 2.7 \\
\hline & & & $\mathrm{FE}$ & 2 & 7 & 4 & 19 & - & 7 & - & - & - & - & 39 & 20.9 \\
\hline & Master's degree & & FE & - & 4 & & 6 & - & - & - & - & - & - & 10 & 5.3 \\
\hline & Total & & & 5 & 27 & 5 & 40 & 2 & 81 & - & 25 & - & 2 & 187 & 100 \\
\hline & $\%$ & & & 2.7 & 14.4 & 2.7 & 21.4 & 1.1 & 43.3 & - & 13.3 & - & 1.1 & 100 & \\
\hline
\end{tabular}


$26.2 \%$ of the participants in the questionnaire were FEs, $31 \%$ were Rs and $42.8 \%$ were FWs. Sixty percent of these people are elementary school graduates, $10 \%$ have associate degrees, $24 \%$ have bachelor's degrees, and $6 \%$ have graduate degrees. The forester groups that participate in certification operations consist of $6.5 \%$ women and $94 \%$ men. Sixty percent of these people are elementary school graduates, $10 \%$ have associate degrees, $24 \%$ have bachelor's degrees, and $6 \%$ have graduate degrees. While workers and public servants are of 41-50 age group, engineers are typically aged 3040 years.

\section{Survey design and statistical analyses}

The results of the study were obtained from questionnaire forms designed to determine foresters' thoughts about and expectations from FMC. Following the first part of the questionnaire about the general characteristics of the forestry personnel, opinions and evaluations of the participants about SFM, forest certification, objectives of certification, contribution of certification to forestry, and the changes that certification will bring about in forestry activities were examined. In the last part, expectations of the participants about possible developments after certification were queried. The questionnaire questions were prepared as closed and open-ended questions. Some questions are for obtaining descriptive information. In general, when asked about perceptions and expectations, questions were prepared on a 5-point Likert scale. The response options were as follows: agree $=5$, partly agree $=4$, neither agree, nor disagree $=3$, partly disagree $=2$, and disagree $=1$. Surveys were conducted through face-to-face interviews. The questionnaires were first tested with a preliminary application, after which the necessary revisions were made.

The $\mathrm{H}_{0}$ hypothesis was formulated as "there is no difference between the perceptions and expectations among staff groups' about FMC," and the $\mathrm{H}_{1}$ hypothesis was formulated as "there is a difference among the staff groups' perceptions and expectations of staff groups about FMC." The statistical analyses were performed using the SPSS 17 Statistics Package Program. The Cronbach's alpha coefficient was calculated at 0.788 . Descriptive statistics were used to analyze the data and one-way analyses of variance (ANOVA) $(\mathrm{p}=0.05)$ were used to measure significant differences between means (Özdamar, 2002; Vidal et al., 2005; Büyüköztürk, 2010), whereas correspondence analysis (Toksoy et al., 2008) was used for testing the hypothesis. When there was a statistical significance $(p=0.05)$, the differences between the groups were analyzed using a post hoc test. Tukey test was used variance was equal $(p>0.05)$, and Tamhane's T test was used when variances were different (Özdamar, 2002).

SCA is a useful method for evaluating two-dimension spaces so that values are geometrically shown by rows and columns forming a contingency table. When the contingency table identifies clustered dots, this may signal problems with the data (Toksoy et al., 2008). To asses whether or not there is a problem, researchers conduct a three-stage analytic process of compatibility analysis (Clausen, 1998). In order to determine both inter-relations and intra-relations between two different categorical variables a suitable multivariate technique, Simple Correspondence Analysis (SCA) is built by reviewing the closeness and remoteness between them (Başpınar and Mendes, 2000; Bendixen, 2003; Aktürk, 2004; Abdi and Bera, 2014). SCA reduces the dimensionality of contingency tables arranged from categorical data (Özdamar, 2002). Compared to other statistical techniques such as Chi-square analysis, G-tests, Z-tests, Fisher Exact tests, or Log-linear models, SCA presents data more visually so that 
reserachers are more easily able to see data relationships (Devillers ve Karcher, 1991; Greenacre, 1998; Başpınar and Mendes, 2002; Özdamar, 2002). Variable levels studied through SCA are represented with a dot in a two-dimensional space. Dots shown to be closer to one another are more closely related and correlated, whereas dots represented as further from each other are not as strongly related (Dunteman, 1989).

SCA is a useful method for evaluating two-dimension spaces so that values are geometrically shown by rows and columns forming a contingency table. When the contingency table identifies clustered dots, this may signal problems with the data (Lee, 1996). To asses whether or not there is a problem, researchers conduct a three-stage analytic process of compatibility analysis (Clausen, 1998).

In running SCA for this study, $\mathrm{X}$ and $\mathrm{Y}$ variables acquired $\mathrm{N}$ monad and are illustrated as $\mathrm{k} 1 * \mathrm{k} 2$ in a dimensional cross section table (Table 4). Row and column profiles were first calculated; second, row and column profiles were drawn the same a two-dimensional space; and finally, these profiles were shown on a two-dimensional map. In order to understand SCA, it is necessary to describe the profile, mass, and chisquare distance and total inertia.

Table 4. $k 1 * k 2$ dimensional cross selection table

\begin{tabular}{|c|c|c|c|c|c|c|}
\hline \multirow{7}{*}{$\mathrm{x}\left(\mathrm{r}_{\mathrm{i}}\right)$} & & \multicolumn{4}{|c|}{$\mathrm{y}(\mathrm{ci})$} & \multirow{3}{*}{ Total $\left(f_{+i}\right)$} \\
\hline & & $\mathrm{y}_{1}$ & $\mathrm{y}_{2}$ & & $\mathrm{y}_{\mathrm{i}}$ & \\
\hline & $\mathrm{x}_{1}$ & $\mathrm{f}_{11}$ & $\mathrm{f}_{12}$ & $\ldots$ & $f_{1 j}$ & \\
\hline & $\mathrm{x}_{2}$ & $\mathrm{f}_{21}$ & $\mathrm{f}_{22}$ & $\ldots$ & $\mathrm{f}_{2 \mathrm{j}}$ & $\mathrm{f}_{2+}$ \\
\hline & : & : & $:$ & & $:$ & $:$ \\
\hline & $\mathrm{i}$ & $\mathrm{f}_{31}$ & $\mathrm{f}_{32}$ & $\ldots$ & $\mathrm{f}_{\mathrm{ij}}$ & $f_{i+}$ \\
\hline & Total $\left(f_{i+}\right)$ & $\mathrm{f}_{-1}$ & $\mathrm{f}_{-2}$ & $\ldots$ & $f_{-j}$ & $\mathrm{f}$ \\
\hline
\end{tabular}

$f_{i j}$ : Frequency value of column $i$ and row $j$

f: Total number of observation

Profiles: When creating a contingency table, frequencies should not be sown in each cell because each row and column contains different responses. Relative frequency was instead calculated as 1 value for each row and column (Greenacre, 1998; Eqs. 2 and 3).

$$
\begin{gathered}
\text { Row profiles: } r_{i j}=f_{i j} / f_{i+} \\
\text { Column profiles: } c_{i j}=f_{i j} / f_{+j}
\end{gathered}
$$

Mass is defined by dividing marginal frequencies by the sum of rows and columns. This system of calculating mass provides an equal contribution for every answer and every profile point. In this analysis, masses are a way to measure the importance of a given profile (Uzgoren, 2007; Eqs. 4 and 5).

$$
\begin{gathered}
\text { Row Mass: } \mathrm{RM}=\mathrm{f}_{\mathrm{i}+} / \mathrm{f} \\
\text { Column Mass: } \mathrm{CM}=\mathrm{f}_{+\mathrm{j}} / \mathrm{f}
\end{gathered}
$$


Chi-square distances: In SCA, the distances of every categories to other one is defined as chi-square distances. Firstly, expected (theoretic) values (tij) of frequencies (fij) in cells are calculated (Eqs. 6 and 7).

$$
\mathrm{t}_{\mathrm{ij}}: \operatorname{mass}_{\mathrm{i}} \mathrm{x} \operatorname{mass}_{\mathrm{j}} \mathrm{x} \mathrm{N}=\left(\mathrm{f}_{\mathrm{i}+}+\mathrm{f}_{+\mathrm{j}}\right) / \mathrm{N}
$$

Then, chi-square values of every cells are calculated with this formula:

$$
\mathrm{x}_{\mathrm{ij}}^{2}=\left(\mathrm{f}_{\mathrm{ij}}-\mathrm{t}_{\mathrm{ij}}\right)^{2} / \mathrm{t}_{\mathrm{ij}}
$$

Total inertia $\left(\Lambda^{2}\right)$ : Variance notion, in SCA, is associated with chi-square distances. For this, generally inertia notion is accepted and inertia is used as synonym with variance notion. Total inertia is the measured distance about the distribution of profile points around the centre, which can be calculated by the below-mentioned formula (Ozdamar, 2002; Eqs. 8 and 9):

$$
\begin{aligned}
& \text { Intertia }_{\mathrm{i}}: \mathrm{x}_{\mathrm{i}}^{2} / \mathrm{x}_{\mathrm{i}+}^{2} \\
& \text { Intertia }_{\mathrm{j}}: \mathrm{x}^{2} / \mathrm{x}^{2}{ }_{+\mathrm{j}}
\end{aligned}
$$

SCA also can be understood as a technique for representing the chi-square (or Phisquare $\phi^{2}=\left(x^{2} / f\right)=\Lambda^{2}=$ total inertia) value of a frequencies table (Clausen, 1998). Total inertia decomposes by an eigenvalue cluster. In a bidirectional table, the number of eigenvalues and also number of dimensions are equal to minimum of (i-1) and (j-1) (Anonymus, 2017). These eigenvalues convey the comparative importance of dimensions and calculate the percentage of total inertia for every dimension. When eigenvalue of data matrix is computed, total inertia is maximum at the first dimension, then begins to decrease in subsequent dimensions (Clausen, 1998).

\section{Results}

The survey was conducted on 187 forestry workers working in certified FDDs in study area. Firstly, SCA results where views of the forester groups on SFM and FMC were assessed were presented (see Tables 5-13). Then, Likert scale average scores (see Tables 14 and 15), ANOVA and post hoc test results (see Table 16), where the forester groups were tested for their expectations about possible developments that may take place after FMC and whether or not there was a difference between the forester groups in terms of their expectations, were included.

\section{Participants' views on SFM and FMC}

To determine the level of awareness of the forester groups about SFM, they had to answer the following question: "In your opinion, which component of SFM is the most important?" (Question 1). Before asking the question, the participants were explained that SFM is composed of economic (a type of management which yields more returns regarding wood and non-wood forestry products), ecologic (a type of management that 
respects the environment and focuses on protecting the environment), and social (a type of management that protects the rights of the local societies and forest workers) (Rahman, 2015). The participant's views were tested by SCA. Frequency values of the SCA analysis results are shown in Table 5. Similarly, Table 6 shows the row and column profiles and Table 7 indicates the inertia, chi-square, significance level, standard error, and correlation values. Figure 2 shows the tendencies of forester groups regarding the components of SFM.

Table 5. Correspondence table: frequencies of people's responses about the questionnaire

\begin{tabular}{c|c|c|c|c|c|c|c|c}
\hline \multirow{2}{*}{ Forester groups } & \multicolumn{7}{|c}{ The most important SFM component } \\
\cline { 2 - 9 } & Ecologic & \% & Social & \% & Economic & \% & Active Margin & \% \\
\hline FE & 31 & 62.0 & 19 & 38.0 & 0 & 0.0 & 50 & 100 \\
R & 29 & 50.9 & 24 & 42.1 & 4 & 7.0 & 57 & 100 \\
FW & 40 & 50.6 & 32 & 40.5 & 7 & 8.9 & 79 & 100 \\
\hline Active Margin & 100 & 53.8 & 75 & 40.3 & 11 & 5.9 & 186 & 100 \\
\hline
\end{tabular}

Table 6. Row and column profiles

\begin{tabular}{|c|c|c|c|c|c|c|c|c|c|}
\hline \multicolumn{5}{|c|}{ Row profiles } & \multicolumn{5}{|c|}{ Column profiles } \\
\hline \multirow{2}{*}{$\begin{array}{l}\text { Forester } \\
\text { groups }\end{array}$} & \multicolumn{4}{|c|}{$\begin{array}{c}\text { The most important SFM } \\
\text { component }\end{array}$} & \multirow{2}{*}{$\begin{array}{l}\text { Forester } \\
\text { groups }\end{array}$} & \multicolumn{4}{|c|}{ The most important SFM component } \\
\hline & 1 & 2 & 3 & $\begin{array}{l}\text { Active } \\
\text { Margin }\end{array}$ & & 1 & 2 & 3 & Mass \\
\hline FE & 0,620 & 0,380 & 0,000 & 1,000 & $\mathrm{FE}$ & 0,310 & 0,253 & 0,000 & 0,269 \\
\hline $\mathrm{R}$ & 0,509 & 0,421 & 0,070 & 1,000 & $\mathrm{R}$ & 0,290 & 0,320 & 0,364 & 0,306 \\
\hline $\mathrm{FW}$ & 0,506 & 0,405 & 0,089 & 1,000 & $\mathrm{FW}$ & 0,400 & 0,427 & 0,636 & 0,425 \\
\hline Mass & 0,538 & 0,403 & 0,059 & & $\begin{array}{l}\text { Active } \\
\text { margin }\end{array}$ & 1,000 & 1,000 & 1,000 & \\
\hline
\end{tabular}

*These values show comparative frequencies. The values in the last row are row mass values

Table 7. Summary table of SCA results on the views of foresters regarding the SFM component they considered most important

\begin{tabular}{|c|c|c|c|c|c|c|c|c|}
\hline \multirow{3}{*}{ Dimension } & \multirow{3}{*}{$\begin{array}{l}\text { Singular } \\
\text { value }\end{array}$} & \multirow{3}{*}{ Inertia } & \multirow{3}{*}{$\begin{array}{l}\text { Chi- } \\
\text { square }\end{array}$} & \multirow{3}{*}{ Sig. } & \multicolumn{2}{|c|}{ Proportion of inertia } & \multicolumn{2}{|c|}{$\begin{array}{c}\text { Confidence singular } \\
\text { value }\end{array}$} \\
\hline & & & & & \multirow{2}{*}{$\begin{array}{l}\text { Accounted } \\
\text { for }\end{array}$} & \multirow{2}{*}{ Cumulative } & \multirow{2}{*}{$\begin{array}{l}\text { Standard } \\
\text { deviation }\end{array}$} & Correlation \\
\hline & & & & & & & & 2 \\
\hline 1 & 0,166 & 0,028 & & & 0,988 & 0,988 & 0,038 & 0,144 \\
\hline 2 & 0,019 & 0,000 & & & 0,012 & 1,000 & 0,075 & \\
\hline Total & & 0,028 & 5,210 & 0,266 & 1,000 & 1,000 & & \\
\hline
\end{tabular}

In terms of the three main objectives of SFM is based on, $53.8 \%$ of the participants found ecological dimension the most important, $40.3 \%$ of the participants found social dimension and $5.9 \%$ of the participants found economic dimension the most important. According to the SCA analysis, all groups seem to agree on the importance of the 
ecological basis of SFM. However, the social basis of SFM is not seen very important by FE. The group that considers this component of SFM as the most important component is the $\mathrm{R}$ group. The group that sees the economic dimension of SFM as the most important component is the FWs.

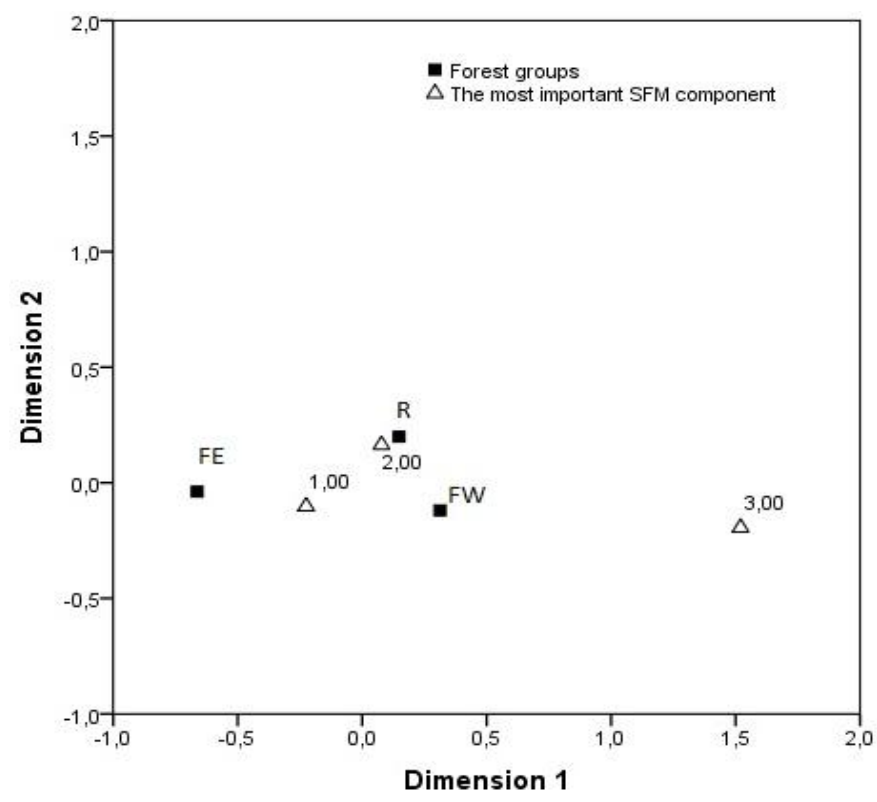

Figure 2. Row and column points symmetrical normalization (for perceptions of forest groups about SFM component). 1: Ecological (forest management with respect for environment and focused on environmental protection). 2: Social (forest management protecting rights of local people and FWs). 3: Economic (it is a management that yields more return in terms of production of wood and non-wood forest products)

We asked the participants a close-ended question, "What do you think the purpose of FMC is?" to determine the views of forester groups on the purposes of FMC (Question 2). The following three propositions were provided to the participants: a) to encourage the most appropriate way of management for all the forests around the world, b) to help manage forestry activities in accordance with the principles of SFM and to spread it internationally, and c) to assure protection and lasting presence of forested areas. The views of the participants regarding the purposes of FMC/Frequency values of the SCA analysis results were tested by SCA and the results are shown in Table 8. Similarly, Table 9 shows the row and column profiles, and Table 10 indicates the inertia, chisquare, significance level, standard error, and correlation values. Figure 3 shows the tendencies of forester groups regarding the purposes of FMC.

Table 8. Correspondence table: frequencies of people's responses about the questionnaire

\begin{tabular}{c|c|c|c|c|c|c|c|c}
\hline \multirow{2}{*}{ Forester groups } & \multicolumn{7}{|c}{ Objectives of forest certification } \\
\cline { 2 - 9 } & $\mathbf{1}$ & $\mathbf{\%}$ & $\mathbf{2}$ & $\mathbf{\%}$ & $\mathbf{3}$ & $\boldsymbol{\%}$ & Active margin & \% \\
\hline FE & 11 & 23.9 & 23 & 50.0 & 12 & 26.1 & 46 & 100 \\
R & 18 & 32.7 & 22 & 40.0 & 15 & 27.3 & 55 & 100 \\
FW & 35 & 44.9 & 16 & 20.5 & 27 & 34.6 & 78 & 100 \\
\hline Active margin & 64 & 35.8 & 61 & 34.1 & 54 & 30.1 & 179 & 100 \\
\hline
\end{tabular}


Table 9. Row and column profiles

\begin{tabular}{|c|c|c|c|c|c|c|c|c|c|}
\hline \multicolumn{5}{|c|}{ Row profiles } & \multicolumn{5}{|c|}{ Column profiles } \\
\hline \multirow{2}{*}{$\begin{array}{l}\text { Forester } \\
\text { groups }\end{array}$} & \multicolumn{4}{|c|}{ Objectives of forest certification } & \multirow{2}{*}{$\begin{array}{c}\text { Forester } \\
\text { groups }\end{array}$} & \multicolumn{4}{|c|}{ Objectives of forest certification } \\
\hline & 1 & 2 & 3 & $\begin{array}{l}\text { Active } \\
\text { margin }\end{array}$ & & 1 & 2 & 3 & Mass \\
\hline $\mathrm{FE}$ & 0,239 & 0,500 & 0,261 & 1,000 & $\mathrm{FE}$ & 0,172 & 0,377 & 0,222 & 0,257 \\
\hline $\mathrm{R}$ & 0,327 & 0,400 & 0,273 & 1,000 & $\mathrm{R}$ & 0,281 & 0,361 & 0,278 & 0,307 \\
\hline $\mathrm{FW}$ & 0,449 & 0,205 & 0,346 & 1,000 & FW & 0,547 & 0,262 & 0,500 & 0,436 \\
\hline Mass & 0,358 & 0,341 & 0,302 & & $\begin{array}{l}\text { Active } \\
\text { margin }\end{array}$ & 1,000 & 1,000 & 1,000 & \\
\hline
\end{tabular}

These values show comparative frequencies. The values in the last row and column are row mass and column values

Table 10. Summary table of SCA results on the views of the foresters regarding the objectives of certification

\begin{tabular}{|c|c|c|c|c|c|c|c|c|}
\hline \multirow{3}{*}{ Dimension } & \multirow{3}{*}{$\begin{array}{l}\text { Singular } \\
\text { value }\end{array}$} & \multirow{3}{*}{ Inertia } & \multirow{3}{*}{$\begin{array}{c}\text { Chi- } \\
\text { square }\end{array}$} & \multirow{3}{*}{ Sig. } & \multicolumn{2}{|c|}{ Proportion of inertia } & \multicolumn{2}{|c|}{$\begin{array}{c}\text { Confidence singular } \\
\text { value }\end{array}$} \\
\hline & & & & & \multirow{2}{*}{\begin{tabular}{|c|}
$\begin{array}{c}\text { Accounted } \\
\text { for }\end{array}$ \\
\end{tabular}} & \multirow{2}{*}{ Cumulative } & \multirow{2}{*}{$\begin{array}{l}\text { Standard } \\
\text { deviation }\end{array}$} & \begin{tabular}{|l} 
Correlation \\
\end{tabular} \\
\hline & & & & & & & & 2 \\
\hline 1 & 0,268 & 0,072 & & & 0,995 & 0,995 & 0,070 & $-0,068$ \\
\hline 2 & 0,018 & 0,000 & & & 0,005 & 1,000 & 0,071 & \\
\hline Total & & 0,072 & 120,876 & 0.012 & 1,000 & 1,000 & & \\
\hline
\end{tabular}

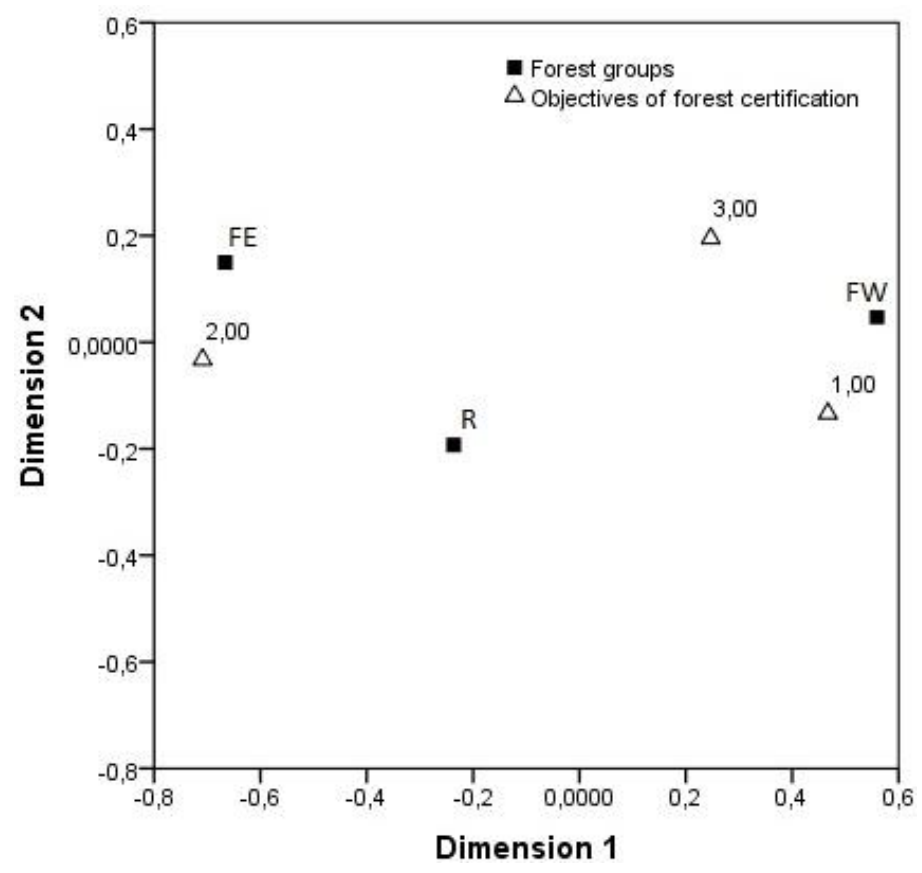

Figure 3. Row and column points symmetrical normalization (for perceptions of forest groups about objectives of FMC). 1: Encouraging the management of all forests in the world most properly. 2: Helping manage forestry according to SFM principles and promoting it internationally. 3: Ensuring preservation and sustainability of forest areas 
Approximately $35.8 \%$ participants thought that the objective of FMC encourages forest management policy selection in the most appropriate way. This was followed by $34.1 \%$ participants considering that forest management according to SFM criteria was effective and as well as followed international. Approximately $30.1 \%$ participants agreed with the view regarding ensuring preservation and sustainability of forest areas. While examining the SCA analysis, it is important for the success of applications to determine the objectives of FMC and which objective is prioritized. These perceptions vary among the workers in the KRDF. The FEs explicitly state that the certification will help manage forestry according to the SFM criteria and will contribute to making the Turkey's forestry products more visible in the international arena. In general, the FWs who live in forest villages and meet their livelihoods with forestry work and agricultural activities hold the view that the objective of certification is to provide preservation and sustainability of forest areas. The Rs, on the other hand, accepted all three viewpoints equally important.

We asked the participants, "has there been a change in your workload during or after the certification?" to determine the effects of FMC on the current workload (Question 3). Table 11 shows the frequency values of the SCA analysis results that measured the views regarding the change in the workload of foresters during certification. Similarly, Table 12 shows the row and column profiles, and Table 13 indicates the inertia, chisquare, significance level, standard error, and correlation values. Figure 4 indicates the direction of the views of the forester groups on the effects of SFM on their workload.

In the analyses regarding the impact of certification on workload were examined, $76.6 \%$ of the participants thought that there was an increase in workload, and $16.3 \%$ think that there was no change in workload. With regard to the individual groups, the general tendency of the FEs among forester groups is that there is an increase in workload.

Table 11. Correspondence table: frequencies of people's responses about the questionnaire

\begin{tabular}{c|c|c|c|c|c|c|c|c}
\hline \multirow{2}{*}{ Forester groups } & \multicolumn{7}{|c}{ Impact of certification on workload } \\
\cline { 2 - 9 } & 1 & $\%$ & 2 & $\%$ & 3 & $\%$ & Active margin & $\%$ \\
\hline FE & 46 & 92.0 & 0 & 0.0 & 4 & 8.0 & 50 & 100 \\
R & 44 & 78.6 & 1 & 1.8 & 11 & 19.6 & 56 & 100 \\
FW & 51 & 65.4 & 12 & 15.4 & 15 & 19.2 & 78 & 100 \\
\hline Active margin & 141 & 76.6 & 13 & 7.1 & 30 & 16.3 & 184 & 100 \\
\hline
\end{tabular}

Table 12. Row and column profiles

\begin{tabular}{|c|c|c|c|c|c|c|c|c|c|}
\hline \multicolumn{5}{|c|}{ Row profiles } & \multicolumn{5}{|c|}{ Column profiles } \\
\hline \multirow{2}{*}{$\begin{array}{c}\text { Forester } \\
\text { groups }\end{array}$} & \multicolumn{4}{|c|}{ Impact of certification on workload } & \multirow{2}{*}{$\begin{array}{c}\text { Forester } \\
\text { groups }\end{array}$} & \multicolumn{4}{|c|}{ Impact of certification on workload } \\
\hline & 1 & 2 & 3 & $\begin{array}{l}\text { Active } \\
\text { margin }\end{array}$ & & 1 & 2 & 3 & Mass \\
\hline FE & 0,920 & 0,000 & 0,080 & 1,000 & FE & 0,326 & 0,000 & 0,133 & 0,272 \\
\hline $\mathrm{R}$ & 0,786 & 0,018 & 0,196 & 1,000 & $\mathrm{R}$ & 0,312 & 0,077 & 0,367 & 0,304 \\
\hline FW & 0,654 & 0,154 & 0,192 & 1,000 & FW & 0,362 & 0,923 & 0,500 & 0,424 \\
\hline Mass & 0,766 & 0,071 & 0,163 & & $\begin{array}{l}\text { Active } \\
\text { margin }\end{array}$ & 1,000 & 1,000 & 1,000 & \\
\hline
\end{tabular}


Table 13. Summary table of SCA results regarding the impact of certification on workload

\begin{tabular}{|c|c|c|c|c|c|c|c|c|}
\hline \multirow{2}{*}{ Dimension } & \multirow{2}{*}{$\begin{array}{l}\text { Singular } \\
\text { value }\end{array}$} & \multirow{2}{*}{ Inertia } & \multirow{2}{*}{$\begin{array}{l}\text { Chi- } \\
\text { square }\end{array}$} & \multirow{2}{*}{ Sig. } & \multicolumn{2}{|c|}{ Proportion of inertia } & \multicolumn{2}{|c|}{$\begin{array}{c}\text { Confidence singular } \\
\text { value }\end{array}$} \\
\hline & & & & & $\begin{array}{c}\text { Accounted } \\
\text { for }\end{array}$ & Cumulative & Standard & \begin{tabular}{|c|} 
Correlation \\
2
\end{tabular} \\
\hline 1 & 0,305 & 0,093 & & & 0,896 & 0,896 & 0,054 & 0,026 \\
\hline 2 & 0,104 & 0,011 & & & 0,104 & 1,000 & 0,066 & \\
\hline Total & & 0,104 & 19,146 & 0,001 & 1,000 & 1,000 & & \\
\hline
\end{tabular}

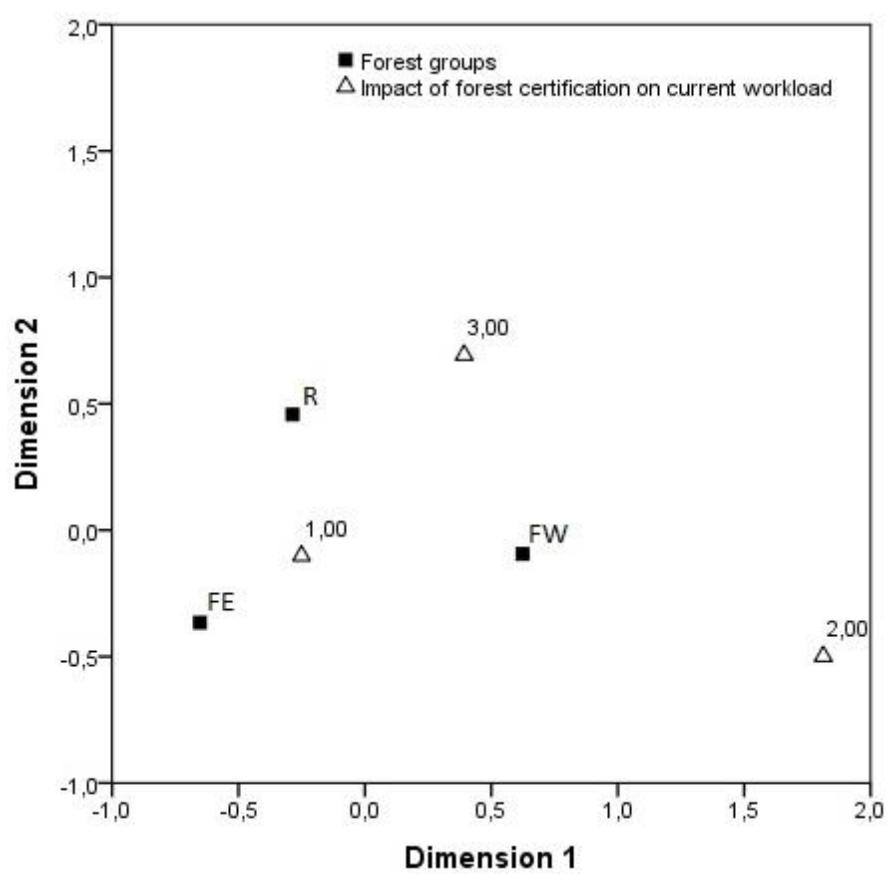

Figure 4. Row and column points symmetrical normalization (for perceptions of forest groups about impact of FMC on workload). 1: There is an increase in workload. 2: There is a decrease in workload. 3: There is no change in workload

The percentage of the Rs who think that there is an increase in workload and the percentage of Rs who think that there is no change in workload were close to each other. Among the FWs, there are participants showing tendency toward all the options and their percentages are close to each other.

When the reasons for this change in workload were examined, the FEs and Rs stated that business security activities, training activities, and paperwork increased after certification and the number of staff is inadequate. The FWs, on the other hand, stated that basic trainings given during the certification process decreased workload.

\section{Expectations of forester groups regarding post-certification conditions}

We also examined the expectations of the participants regarding possible developments that might occur during the certification process. For this purpose, we provided 25 propositions to the participants (Table 14) and asked them whether they agree with these propositions or not (Question 4). Table 15 shows the average Likert 
scores based on the obtained survey results, and Table 16 shows the results of the ANOVA analysis conducted to test the variation among the groups.

\section{Table 14. Propositions about possible developments after certification}

\begin{tabular}{|c|c|}
\hline 1 & Provisions of international agreements will be reflected to practice in a more effective way. \\
\hline 2 & $\begin{array}{l}\text { During the certification process, foresters will be aware of their rights defined by international } \\
\text { conventions and be able to use these rights. }\end{array}$ \\
\hline 3 & $\begin{array}{l}\text { Illegal benefits gained from forests will be decreased as a result of trainings in the certification } \\
\text { process. }\end{array}$ \\
\hline 4 & Professionalization of local people to work in production will be ensured. \\
\hline 5 & Access to and use of non-wood forest products will be recorded. \\
\hline 6 & $\begin{array}{l}\text { Laws will be strictly complied with regarding employment of children, women and young } \\
\text { workers in the forest and they will be given all their rights. }\end{array}$ \\
\hline 7 & Housing and nutrition conditions of the workers performing forestry activities will be improved \\
\hline 8 & Mobbing on exercising the right of unionization and collective bargaining will be eliminated. \\
\hline 9 & Potential conflicts between stakeholders will be identified and solutions will be developed. \\
\hline 10 & Sustainable production plans will be made for non-wood services and products. \\
\hline 11 & Forestry production techniques will be improved and thus production losses will be minimized. \\
\hline 12 & The quality of forest products and services will be improved after certification. \\
\hline 13 & $\begin{array}{l}\text { Employees of forestry organization, especially managers will increase their skills to evaluate } \\
\text { forests in many aspects by improving themselves with the help of trainings. }\end{array}$ \\
\hline 14 & $\begin{array}{l}\text { Before all forestry activities, environmental impact assessment will be done and measures will } \\
\text { be taken wherever required. }\end{array}$ \\
\hline 15 & Expert opinion will be taken in all forestry activities beforehand. \\
\hline 16 & Preservation of wetlands will be provided. \\
\hline 17 & $\begin{array}{l}\text { Creation of natural corridors will be provided wherever required by preventing deterioration of } \\
\text { forests. }\end{array}$ \\
\hline 18 & $\begin{array}{l}\text { Monitoring, mapping, and registration of forestry activities and social, economic, and ecologica } \\
\text { effects of these activities will be provided. }\end{array}$ \\
\hline 19 & $\begin{array}{l}\text { Environmental and social impact assessment, identification, and protection of endangered } \\
\text { species and descriptions of production techniques and equipment will be added to management } \\
\text { plans. }\end{array}$ \\
\hline 20 & Results of monitoring plans will be shared with the public. \\
\hline 21 & $\begin{array}{l}\text { Forests with high preservation value will be identified with the support of stakeholders and } \\
\text { experts and will be managed with a participative management mentality. }\end{array}$ \\
\hline 22 & $\begin{array}{l}\text { It will be paid more attention to occupational safety and health issues in forestry activities (use } \\
\text { of personal protective equipment, first aid, etc.). }\end{array}$ \\
\hline 23 & Awareness of stakeholders about endangered species will be increased. \\
\hline 24 & Efficiency of stakeholders in forestry management will be increased. \\
\hline 25 & $\begin{array}{l}\text { The sales prices of products and services obtained from certificated forests will increase } \\
\text { according to the existing values. }\end{array}$ \\
\hline
\end{tabular}


Table 15. Likert results on the propositions about possible developments after certification

\begin{tabular}{|c|c|c|c|c|c|c|c|c|c|c|c|c|c|c|}
\hline \multicolumn{2}{|c|}{ Expectations after FMC } & 1 & 2 & 3 & 4 & 5 & 6 & 7 & 8 & 9 & 10 & 11 & 12 & 13 \\
\hline \multirow{3}{*}{ 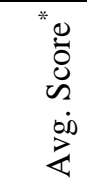 } & $\mathrm{FE}$ & 4.2 & 4.1 & 3.5 & 3.9 & 3.8 & 3.9 & 4.1 & 3.8 & 4 & 4 & 4.2 & 4.2 & 4.3 \\
\hline & $\mathrm{R}$ & 3.8 & 3.7 & 3.7 & 3.7 & 3.7 & 3.8 & 3.6 & 3.6 & 3.6 & 3.8 & 3.8 & 3.7 & 3.6 \\
\hline & FW & 3.6 & 3.7 & 3.8 & 3.8 & 3.8 & 3.8 & 3.6 & 3.7 & 3.5 & 3.9 & 3.8 & 3.8 & 3.7 \\
\hline \multicolumn{2}{|c|}{ Expectations after FMC } & 14 & 15 & 16 & 17 & 18 & 19 & 20 & 21 & 22 & 23 & 24 & 25 & \\
\hline \multirow{3}{*}{ 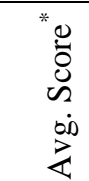 } & FE & 4.2 & 3.9 & 4.1 & 3.9 & 4.4 & 4.2 & 4.2 & 4.1 & 4.4 & 4.2 & 4 & 4 & \\
\hline & $\mathrm{R}$ & 3.7 & 3.7 & 3.7 & 3.7 & 3.8 & 3.7 & 3.7 & 3.8 & 3.8 & 3.8 & 3.8 & 3.8 & \\
\hline & FW & 3.8 & 3.7 & 3.9 & 3.7 & 3.8 & 3.8 & 3.8 & 3.8 & 3.8 & 3.9 & 3.8 & 3.8 & \\
\hline
\end{tabular}

*Agree (5.5-4.6), partly agree (4.5-3.6), neither agree nor disagree (3.5-2.6), partly disagree (2.5-1.6), disagree $(1.5-0.5)$

Table 16. ANOVA results on the views of the foresters regarding possible developments after certification

\begin{tabular}{|c|c|c|c|c|c|c|c|c|}
\hline \multicolumn{8}{|c|}{ ANOVA results } & \multirow{2}{*}{\begin{tabular}{|c|}
$\begin{array}{c}\text { Post hoc } \\
\text { test results }\end{array}$ \\
Differences \\
between the \\
groups
\end{tabular}} \\
\hline $\begin{array}{c}\text { Dependent } \\
\text { variables }\end{array}$ & $\begin{array}{l}\text { Source of } \\
\text { variance }\end{array}$ & $\begin{array}{c}\text { Sum of } \\
\text { squares }\end{array}$ & df & $\begin{array}{c}\text { Mean } \\
\text { square }\end{array}$ & $\mathbf{F}$ & $\mathbf{p}$ & $\begin{array}{l}\text { Significant } \\
\text { difference }\end{array}$ & \\
\hline 1 & $\begin{array}{c}\text { Between groups } \\
\text { Within groups } \\
\text { Total }\end{array}$ & $\begin{array}{c}9,074 \\
132,113 \\
141,187\end{array}$ & $\begin{array}{c}2 \\
184 \\
186 \\
\end{array}$ & $\begin{array}{l}4,537 \\
0,718\end{array}$ & 6,319 & 0,002 & Yes & FE - FW \\
\hline 2 & $\begin{array}{c}\text { Between groups } \\
\text { within groups } \\
\text { Total }\end{array}$ & $\begin{array}{c}6,275 \\
174,003 \\
180,278\end{array}$ & $\begin{array}{c}2 \\
184 \\
186\end{array}$ & $\begin{array}{l}3,137 \\
.946\end{array}$ & 3,318 & 0,038 & Yes & FE - FW \\
\hline 3 & $\begin{array}{c}\text { Between groups } \\
\text { Within groups } \\
\text { Total }\end{array}$ & $\begin{array}{c}2,352 \\
169,274 \\
171,626\end{array}$ & $\begin{array}{c}2 \\
184 \\
186\end{array}$ & $\begin{array}{l}1,176 \\
0,920\end{array}$ & 1,278 & 0,281 & No: & - \\
\hline 4 & $\begin{array}{c}\text { Between groups } \\
\text { Within groups } \\
\text { Total }\end{array}$ & $\begin{array}{c}1,366 \\
141,703 \\
143,070 \\
\end{array}$ & $\begin{array}{c}2 \\
184 \\
186 \\
\end{array}$ & $\begin{array}{l}0,683 \\
0,770\end{array}$ & 0,887 & 0,414 & No: & - \\
\hline 5 & $\begin{array}{c}\text { Between groups } \\
\text { within groups } \\
\text { Total }\end{array}$ & $\begin{array}{c}0,216 \\
146,896 \\
147,112 \\
\end{array}$ & $\begin{array}{c}2 \\
184 \\
186 \\
\end{array}$ & $\begin{array}{l}0,108 \\
0,798\end{array}$ & 0,135 & 0,874 & No: & - \\
\hline 6 & $\begin{array}{c}\text { Between groups } \\
\text { Within groups } \\
\text { Total }\end{array}$ & $\begin{array}{c}0,438 \\
161,241 \\
161,679 \\
\end{array}$ & $\begin{array}{c}2 \\
184 \\
186 \\
\end{array}$ & $\begin{array}{l}0,219 \\
0,876\end{array}$ & 0,250 & 0,779 & No: & - \\
\hline 7 & $\begin{array}{c}\text { Between groups } \\
\text { within groups } \\
\text { Total }\end{array}$ & $\begin{array}{c}8,362 \\
154,750 \\
163,112\end{array}$ & $\begin{array}{c}2 \\
184 \\
186\end{array}$ & $\begin{array}{l}4,181 \\
0,841\end{array}$ & 4,971 & 0,008 & Yes & $\begin{array}{c}\mathrm{FE}-\mathrm{R} \\
\mathrm{FE}-\mathrm{FW}\end{array}$ \\
\hline 8 & $\begin{array}{c}\text { Between groups } \\
\text { Within groups } \\
\text { Total }\end{array}$ & $\begin{array}{c}2,080 \\
152,305 \\
154,385\end{array}$ & $\begin{array}{c}2 \\
184 \\
186 \\
\end{array}$ & $\begin{array}{l}1,040 \\
0,828\end{array}$ & 1,256 & 0,287 & No: & - \\
\hline 9 & $\begin{array}{c}\text { Between groups } \\
\text { Within groups } \\
\text { Total }\end{array}$ & $\begin{array}{c}8,745 \\
154,699 \\
163,444\end{array}$ & $\begin{array}{c}2 \\
184 \\
186\end{array}$ & $\begin{array}{l}4,372 \\
0,841\end{array}$ & 5,200 & 0,006 & Yes & $\begin{array}{c}\mathrm{FE}-\mathrm{R} \\
\mathrm{FE}-\mathrm{FW}\end{array}$ \\
\hline
\end{tabular}




\begin{tabular}{|c|c|c|c|c|c|c|c|c|}
\hline 10 & $\begin{array}{c}\text { Between groups } \\
\text { Within groups } \\
\text { Total }\end{array}$ & $\begin{array}{c}1,818 \\
143,594 \\
145,412 \\
\end{array}$ & $\begin{array}{c}2 \\
184 \\
186 \\
\end{array}$ & $\begin{array}{l}0,909 \\
0,780\end{array}$ & 1,165 & 0,314 & No: & - \\
\hline 11 & $\begin{array}{c}\text { Between groups } \\
\text { within groups } \\
\text { Total }\end{array}$ & $\begin{array}{c}6,336 \\
138,733 \\
145,070 \\
\end{array}$ & $\begin{array}{c}2 \\
184 \\
186 \\
\end{array}$ & $\begin{array}{l}3,168 \\
0,754\end{array}$ & 4,202 & 0,016 & Yes & $\mathrm{FE}-\mathrm{FW}$ \\
\hline 12 & $\begin{array}{c}\text { Between groups } \\
\text { Within groups } \\
\text { Total }\end{array}$ & $\begin{array}{c}6,952 \\
153,433 \\
160,385 \\
\end{array}$ & $\begin{array}{c}2 \\
184 \\
186 \\
\end{array}$ & $\begin{array}{l}3,476 \\
0,834\end{array}$ & 4,169 & 0,017 & Yes & $\begin{array}{c}\mathrm{FE}-\mathrm{R} \\
\mathrm{FE}-\mathrm{FW}\end{array}$ \\
\hline 13 & $\begin{array}{c}\text { Between groups } \\
\text { Within groups } \\
\text { Total } \\
\end{array}$ & $\begin{array}{c}13,415 \\
138,970 \\
152,385 \\
\end{array}$ & $\begin{array}{c}2 \\
184 \\
186 \\
\end{array}$ & $\begin{array}{l}6,708 \\
0,755\end{array}$ & 8,881 & 0,000 & Yes & $\begin{array}{c}\mathrm{FE}-\mathrm{R} \\
\mathrm{FE}-\mathrm{FW}\end{array}$ \\
\hline 14 & $\begin{array}{c}\text { Between groups } \\
\text { Within groups } \\
\text { Total }\end{array}$ & $\begin{array}{c}6,334 \\
140,586 \\
146,920\end{array}$ & $\begin{array}{c}2 \\
184 \\
186 \\
\end{array}$ & $\begin{array}{l}3,167 \\
0,764\end{array}$ & 4,145 & 0,017 & Yes & FE - R \\
\hline 15 & $\begin{array}{c}\text { Between groups } \\
\text { Within groups } \\
\text { Total }\end{array}$ & $\begin{array}{c}0,971 \\
151,040 \\
152,011 \\
\end{array}$ & $\begin{array}{c}2 \\
184 \\
186 \\
\end{array}$ & $\begin{array}{l}0,485 \\
0,821\end{array}$ & 0,591 & 0,555 & No: & - \\
\hline 16 & $\begin{array}{c}\text { Between groups } \\
\text { Within groups } \\
\text { Total }\end{array}$ & $\begin{array}{c}3,159 \\
145,483 \\
148,642 \\
\end{array}$ & $\begin{array}{c}2 \\
184 \\
186 \\
\end{array}$ & $\begin{array}{l}1,580 \\
0,791\end{array}$ & 1,998 & 0,139 & No: & - \\
\hline 17 & $\begin{array}{c}\text { Between groups } \\
\text { Within groups } \\
\text { Total }\end{array}$ & $\begin{array}{c}2,290 \\
167,389 \\
169,679\end{array}$ & $\begin{array}{c}2 \\
184 \\
186 \\
\end{array}$ & $\begin{array}{l}1,145 \\
0,910\end{array}$ & 1,259 & 0,286 & No: & - \\
\hline 18 & $\begin{array}{c}\text { Between groups } \\
\text { Within groups } \\
\text { Total }\end{array}$ & $\begin{array}{c}10,705 \\
136,246 \\
146,952 \\
\end{array}$ & $\begin{array}{c}2 \\
184 \\
186 \\
\end{array}$ & $\begin{array}{l}5,353 \\
0,740\end{array}$ & 7,229 & 0,001 & Yes & $\begin{array}{c}\mathrm{FE}-\mathrm{R} \\
\mathrm{FE}-\mathrm{FW}\end{array}$ \\
\hline 19 & $\begin{array}{c}\text { Between groups } \\
\text { Within groups } \\
\text { Total } \\
\end{array}$ & $\begin{array}{c}7,294 \\
122,117 \\
129,412 \\
\end{array}$ & $\begin{array}{c}2 \\
184 \\
186 \\
\end{array}$ & $\begin{array}{l}3,647 \\
0,664\end{array}$ & 5,495 & 0,005 & Yes & $\begin{array}{c}\mathrm{FE}-\mathrm{R} \\
\mathrm{FE}-\mathrm{FW}\end{array}$ \\
\hline 20 & $\begin{array}{c}\text { Between groups } \\
\text { Within groups } \\
\text { Total } \\
\end{array}$ & $\begin{array}{c}7,009 \\
143,376 \\
150,385 \\
\end{array}$ & $\begin{array}{c}2 \\
184 \\
186 \\
\end{array}$ & $\begin{array}{l}3,504 \\
0,779\end{array}$ & 4,497 & 0,012 & Yes & $\begin{array}{c}\mathrm{FE}-\mathrm{R} \\
\mathrm{FE}-\mathrm{FW}\end{array}$ \\
\hline 21 & $\begin{array}{c}\text { Between groups } \\
\text { Within groups } \\
\text { Total }\end{array}$ & $\begin{array}{c}3,041 \\
138,413 \\
141,455\end{array}$ & $\begin{array}{c}2 \\
184 \\
186 \\
\end{array}$ & $\begin{array}{l}1,521 \\
0,752\end{array}$ & 2,022 & 0,135 & No: & - \\
\hline 22 & $\begin{array}{c}\text { Between groups } \\
\text { Within groups } \\
\text { Total }\end{array}$ & $\begin{array}{c}13,966 \\
115,841 \\
129,807\end{array}$ & $\begin{array}{c}2 \\
184 \\
186 \\
\end{array}$ & $\begin{array}{l}6,983 \\
0,630\end{array}$ & 11,092 & 0,000 & Yes & $\begin{array}{c}\mathrm{FE}-\mathrm{R} \\
\mathrm{FE}-\mathrm{FW}\end{array}$ \\
\hline 23 & $\begin{array}{c}\text { Between groups } \\
\text { Within groups } \\
\text { Total }\end{array}$ & $\begin{array}{c}6,369 \\
128,369 \\
134,738 \\
\end{array}$ & $\begin{array}{c}2 \\
184 \\
186 \\
\end{array}$ & $\begin{array}{l}3,185 \\
0,698\end{array}$ & 4,565 & 0,012 & Yes & FE - R \\
\hline 24 & $\begin{array}{c}\text { Between groups } \\
\text { Within groups } \\
\text { Total }\end{array}$ & $\begin{array}{c}1,155 \\
137,765 \\
138,920 \\
\end{array}$ & $\begin{array}{c}2 \\
184 \\
186 \\
\end{array}$ & $\begin{array}{l}0,578 \\
0,749\end{array}$ & 0,771 & 0,464 & No: & - \\
\hline 25 & $\begin{array}{c}\text { Between groups } \\
\text { Within groups } \\
\text { Total } \\
\end{array}$ & $\begin{array}{c}1,426 \\
152,745 \\
154,171 \\
\end{array}$ & $\begin{array}{c}2 \\
184 \\
186 \\
\end{array}$ & $\begin{array}{l}0,713 \\
0,830\end{array}$ & 0,859 & 0,425 & No: & - \\
\hline
\end{tabular}


According to the ANOVA test results, which was conducted to determine whether there were differences between the forester groups' expectations regarding possible developments after FMC, there was a statistically significant difference between the FEs and the FWs regarding the views that the provisions of international agreements would be reflected to practice in a more effective way $(\mathrm{p}=0.002<0.05)$, that during the certification process, foresters would be aware of their rights defined by international conventions and be able to use these rights $(\mathrm{p}=0.038<0.05)$ and that forestry production techniques would be improved and thus production losses would be minimized $(\mathrm{p}=0.016<0.05)$.

There was a statistically significant difference between the FEs and the Rs regarding the views that before all forestry activities, environmental impact assessment would be done and measures would be taken wherever required ( $\mathrm{p}=0.017$ $<0.05)$ and that the awareness of stakeholders about endangered species would be increased $(\mathrm{p}=0.012<0.05)$.

There was statistically significant difference sbetween the FEs and the Rs and between the FEs and the FWs regarding the following changes after FMC ( $p=0.008<$ 0.05): that potential conflicts between stakeholders would be identified and solutions would be developed $(\mathrm{p}=0.006<0.05)$; that the quality of forest products and services would be improved $(\mathrm{p}=0.017<0.05)$; that the employees of the forestry organization, especially managers would increase their skills to evaluate forests in many aspects by improving themselves with the help of trainings $(\mathrm{p}=0.000<0.05)$; that monitoring, mapping and registering all kinds of forestry activities and social, economic and ecological effects of these activities would be provided $(\mathrm{p}=0.001<0.05)$; that environmental and social impact assessment, identification and protection of endangered species and descriptions of production techniques and equipment would be added to management plans $(\mathrm{p}=0.005<0.05)$ that results of monitoring plans would be shared with the public $(\mathrm{p}=0.012<0.05)$ and that it would be paid more attention to occupational safety and health issues in forestry activities (use of personal protective equipment, first aid, etc. $)(\mathrm{p}=0.000<0.05)$.

\section{Discussion}

\section{SFM and FMC}

In certification applications in the regions where private forestry is prevalent, the forest owners is informed in advance regarding the responsibilities they will assume. However, FMC processes in Turkey have started in line with the directives of senior executives of the forest management according to the requests from private companies engaged in export of forest products, because forests are owned by the state in Turkey. Before the certification process, the fact that the employees in the institution except a small number of the FEs had no knowledge about FMC has caused many problems in the certification application.

In many studies worldwide, the certification process conducted particularly in the areas where forests are under human pressure were considered as an important tool for SFM (Rametsteiner and Simula, 2003; Gambetta et al., 2006; Zhao et al., 2011). Therefore, foresters' views on SFM are important for implementation and maintenance of such techniques. However, in addition to considering certification important, knowledge regarding which aspects the forester stakeholders consider important will also be effective in solving the problems encountered in the certification process. 
In the study, when the views of the forester groups on FMC were examined, it was seen that the FEs see certification as a tool for SFM, the FWs approach it as a tool to encourage management of all forests in the world in the most appropriate way and to provide preservation of forest lands. The Rs, on the other hand, evaluate certification from a more general perspective, advocating these three views. The FSC certification organization has more effective criteria particularly in terms of nature conservation and this is reported to be seen as the reason why FSC is preferred in the USA, Canada, and Germany rather than other certification bodies that adopt economics-based approaches (Cashore et al., 2005). In this context, it can be said that the perspective on the certification process in Turkey show alignment with the rest of the world. Although forest certification initially dealt with environmental issues and then addressed social issues, the current economic aspects of certification have been also being discussed (Butterfield et al., 2005). A forest management understanding focused on respect for environment and protection of the environment, which constitutes the first phase of certification, is still on the agenda in Turkey considering that the certification efforts in Turkey begun in 2010. The economic aspect of certification is expected to come into prominence in the coming years with the demands of forest industry organizations for certified assets. Indeed, in a study conducted in $2015,58.2 \%$ of the companies in the forest industry in Turkey indicate that certification is required for forest products (Tolunay et al., 2014).

The concern that the certification process will increase workload is one of the most important causes of negative outlook of foresters for certification. As forester groups are under heavy workload because of excessive bureaucracy, paperwork, and fieldworks presently, it is not actually an unexpected situation that they adopt a negative stance against certification. The fact that all forester groups, and particularly the FEs and the Rs, think that the workload will increase after the certification supports this prediction. One of the important points here is to find the line of work that will have an increase in workload and the causes for it. It was found at the end of the study that according to the FEs and the Rs, particularly because of inadequate staff numbers, there is an increase in workload in the fields such as safety activities, training programs, and paperwork. However, some of the FWs indicate that basic training given in the certification process causes a decrease in workload by allowing a more orderly and planned work. Similarly, in some scientific studies, it is stated that there is a requirement for proper paperwork regulations and an archiving system during adaptation to the FSC standards (Çavdar, 2012), however, it was discovered that paperwork density and redundancy of administrative requirements are seen as a worrying situation particularly in small scale businesses (Bass et al., 2001). In a study in the USA is reported that certification will increase workload in particular (Auld et al., 2003).

\section{Post-certification expectations}

Although a significant amount of material and nonmaterial costs are paid for the certification process, people's expectations for the benefits to be gained from the results of these studies constitute the most important driving force for the success of these processes. In this context, the results obtained in the study show that all forester groups have many positive expectations for the conditions after FMC. However, the FEs think negatively about the proposition that illegal benefits would be decreased after trainings given especially to forest villagers and the FWs think negatively about the proposition 
that conflicts between forester stakeholders would be ended. In general, the FWs and the Rs share the same thoughts with regard to expectations after certification.

Several other conclusions were noted in other studies with regard to such propositions. For example, in a study conducted in Brazil, it was proposed that the FSC certification would increase the value of certified products in economic sense (Azevedo and Freitas, 2003). In a study conducted in Guatemala, the stakeholders adopted the view that "in forest products market, the demand for certified forest products would gain positive momentum" (Rametsteiner and Simula, 2003). Finally, in a study in the American market, the proposition was that certification would provide market security for local products (Auld et al., 2003).

A study on feasibility of certification in Turkey stated that certification is offered as an opportunity for the solution of problems faced by the forest industry in Turkey in terms of economical, institutional, legal, and social problems as well as issues regarding planned tasks (Durusoy, 2002). Moreover, in a study conducted for preservation of the Amazon rainforest, it is indicated that there is improvement in FW rights and an increase in the standards of production activities in the forest after introduction of legislation and in the FSC harmonization process (Azevedo and Freitas, 2003). This is in agreement with the view that certification improve standards.

Inadequacies in the implementation of international agreements in the certification process have been reported. In fact, these inadequacies have been already indicated by the FSC inspectors that international conventions (ILO, CITES, BERN, etc.), which Turkey has signed, cannot be completely applied in Turkey because of "customary local mentalities." This reveals the necessity to make new policies as well as new arrangements in laws and regulations in coming years. In a study conducted in England, it is stated that certification affects forestry policies of the society (Bass et al., 2001).

\section{Conclusion}

In this study, we discovered that the success of FMC applications adopted by forests and managed by state forest enterprises is affected by the personnel structures. Especially if the workplace of the employees, who are in managerial positions, changes frequently and the replacing employees have a lower level of knowledge about certification, work gets delayed. In these cases, if attention is not paid toward the required observation and evaluation efforts for the continuation of certification, this makes the efforts superficial and prevents the certification from reaching the expected purposes.

Especially personnel policies need to be planned well to make sure that the certification practices, which are to be adopted in state-owned forested areas, are successful and provide the expected contributions. Filling the vacancies would increase the chances of success and sustainability of the efforts. In addition, it is necessary to conduct risk assessments and social impact evaluations before ensuring improvements in the use of legal rights owned by the forester groups. These generally include occupational safety and efficient labor issues, implementation of participatory management model, and creation and implementation of a management model.

It is wiser for countries to create their own national standards without deviating from the main purposes of certification rather than applying the standards determined by a certain certification institution due to their different legal, social, and physical structures. Certification efforts conducted in accordance with the standards that would 
be determined according to the domestic dynamics of countries would make it possible to solve many of the current problems at the very beginning. However, the most important two points that need to be applied to this type of a system are to keep the protection of forests and participatory approach in the foreground and having the audits always conducted by independent institutions.

With increasing the awareness of the groups forming the forestry association regarding sustainability and certification, trust in the certifications efforts that the expected benefits of certification would be realized in time and accordingly, the health, and sustainability of the forests would be guaranteed, is one of the most positive factors in the certification efforts.

Acknowledgments. This research did not receive any specific grant from funding agencies in the public, commercial, or not-for-profit sectors. Gökhan Şen designed the research, coordinated the data analysis and wrote to the paper. Adem Genç conducted survey studies and contributed to revising the manuscript. The authors declare no conflict of interest.

\section{REFERENCES}

[1] Abdi, H., Bera, M. (2014): Correspondence analysis. - https://cedric.cnam.fr/ fichiers/art_3066.pdf (accessed on 30.07.2017).

[2] Aktürk, D. (2004): Use of multiple correspondence analysis technique in social science research. - Tarım Bilimleri Dergisi 10(2): 218-221.

[3] Akyol, A., Tolunay, A. (2006): Sustainable forest resources management, policies, indicators and applications in Turkey. - Süleyman Demirel University Journal of the Institute of Science and Technology 10-2: 221-234.

[4] Anonymous (2014). Kastamonu province state of the environment report 2014. T.C. Kastamonu Valiliği Çevre ve Şehircilik İl Müdürlüğü (p. 174). Kastamonu, Turkey. http://www.csb.gov.tr/ db/ced/editordosya/Kastamonu\%202014.pdf (accessed on 13.07.2016).

[5] Anonymous (2017). How to analyze simple two-way and multi-way table, correspondence analysis. - http://www.statsoft.com/Textbook/Correspondence-Analysis (accessed on 04.010.2017).

[6] Asan, Ü. (2010): Turkey forest management from past to now. Forest management's past, present and future workshop conclusions and papers, 42-76, Antalya, Turkey. https://www.ogm.gov.tr/ekutuphane/EgitimDokumanlari/Orman\%20\%C4\%B0daresi\%20 ve\%20Planlama\%20Dairesi\%20Ba\%C5\%9Fkanl\%C4\%B1\%C4\%9F\%C4\%B1/AMENAJ MAN\% 20\%C4\%B0LE\% $20 \% \mathrm{C} 4 \%$ B0LG\%C4\%B0L\%C4\%B0\%20KAYNAKLAR/SEM POZYUMLAR/Amenajman\%20\%C3\%A7al\%C4\%B1\%C5\%9Ftay\%C4\%B1\%20kitab\% C4\%B1\%2005.08.2010.pdf (accessed on 08.08.2017).

[7] Auld, G., Cashore, B., Newsome, D. (2003): Forest Policy for Private Forestry: Global and Regional Challenges, Chapter 25: Perspectives on Forest Certification: A Survey Examining Differences Among the US Forest Sector' Views of Their Forest Certification Alternatives. - CABI Publishing, Wallingford.

[8] Ayan, S., Öztürk, S., Yiğit, N. (2009): Suitability for certification system of protected area network in Black Sea region's national parks. - Kastamonu University Journal of Forest Faculty 9(1): 66-79.

[9] Azevedo, T. R., Freitas, A. G. (2003): The parallel evolution of community forest management in the Brazilian Amazon and FSC certification. - Forest Trends. http://www.forest-trends.org/publication_details.php?publicationID $=321$ (accessed on 29.06.2017). 
[10] Bass, S., Thornber, K., Markopoulos, M., Robert, S., Grieg-Gran, M. (2001): Certification's Impacts on Forests, Stakeholders and Supply Chains. - Russell Press, Nottingham, UK.

[11] Baspinar E., Mendes, M. (2000): The usage of correspondence analysis technique at the contingency tables. - Ankara Üniversitesi Ziraat Fakültesi Tarim Bilimleri Dergisi 6(2): 98-106.

[12] Bendixen, M. (2003): A practical guide to the use of correspondence analysis in marketing research. - Marketing Bulletin 14(2): 1-15. http://citeseerx.ist.psu.edu/viewdoc/download?doi=10.1.1.583.4842\&rep=rep1\&type=pdf (accessed on 14.05.2017).

[13] Brockhause, M., Botoni, E. (2009): Ecosystem services-local benefits, global impacts. Rural 21 The International Journal for Rural Development 43(1): 8-32.

[14] Butterfield, R., Hansen, E., Fletcher, R., Nikinmaa, H. (2005): Forest certification and small forest enterprises: key trends and impacts - benefits and barriers. Forest Trends and Rainforest Alliance. - $\quad$ Forest Trends. http://www.foresttrends.org/documents/files/doc_114.pdf (accessed on 12.12.2016).

[15] Büyüköztürk, Ş. (2010): Data Analysis Handbook for the Social Sciences. - Pagem Akademi, Ankara, Turkey.

[16] Carrera, F., Stoian, D., Campos, J. J., Morales, J., Pinelo, G. (2004): Forest certification in Guatemala. - Symposium of Forest Certification in Developing and Transitioning Societies: Social, Economic, and Ecological Effects. - Yale School of Forestry and Environmental Studies, New Haven, USA. https://pdfs.semanticscholar.org/c09e/689837f59f2eaef40d6ac8b494 ee45071407.pdf (accessed on 02.04.2016).

[17] Cashore, B., Auld, G., Newsom, D. (2002): Forest certification (eco-labeling) programs and their policy-making authority: explaining divergence among North American and European case studies. - Forest Policy and Economics 5: 225-247.

[18] Cashore, B., Kooten, G. C., Vertinsky, I., Auld, G., Affolderbach, J. (2005): Private or self-regulation? A comparative study of forest certification choices in Canada, the United States and Germany. - Forest Policy and Economics 7(1): 53-69.

[19] CICI (2003): Report of the international conference on the contribution of criteria and indicators for sustainable forest management: the way forward. Final report, February 3-7 2003, Guatemala City, Guatemala. http://www.fao.org/docrep/005/Y8694E/Y8694e04.htm (accessed on 15.06.2017).

[20] Clausen, S. E. (1998): Applied Correspondence Analysis-An Introduction. - Sage Publication, Thousand Oaks, USA.

[21] Cubbage F., Harou P., Sills E. (2007): Policy instruments to enhance multi-functional forest management. - Forest Policy and Economics 9(7): 833-851.

[22] Çavdar, B. (2012): The evaluation of Arvin forestry enterprise in certification process. Master Thesis, Artvin Çoruh University Institute of Natural and Applied Sciences, Artvin, Turkey.

[23] Devillers, J., Karcher, W. (1991): Applied Multivariate Analysis in SAR and Environmental Studies. - Kluwer, Dordrecht, Netherlands.

[24] Dunteman, G. H. (1989): Principal Components Analysis. - Sage Publication, Inc., Thousand Oaks, California, USA.

[25] Durusoy, İ. (2002): Certification and analysis of necessity, applicability and possible problems and opportunities to application process in Turkish forestry. - Master Thesis, Karadeniz Technical University Institute of Natural and Applied Sciences, Trabzon, Turkey.

[26] Eler, Ü. (2010): Turkey forest management from past to now. - Forest management's past, present and future workshop conclusions and papers 42-76, Antalya, Turkey. https://www.ogm.gov.tr/ekutuphane/EgitimDokumanlari/Orman\%20\%C4\%B0daresi\%20 ve\%20Planlama\%20Dairesi\%20Ba\%C5\%9Fkanl\%C4\%B1\%C4\%9F\%C4\%B1/AMENAJ 
MAN\%20\%C4\%B0LE\%20\%C4\%B0LG\%C4\%B0L\%C4\%B0\%20KAYNAKLAR/SEM POZYUMLAR/Amenajman\%20\%C3\%A7al\%C4\%B1\%C5\%9Ftay\%C4\%B1\%20kitab\% C4\%B1\%2005.08.2010.pdf (accessed on 01.08.20177).

[27] Eryılmaz, A. Y., Tolunay, A. (2015): Ormancılık Politikası. - Fakülte Kitabevi, Isparta, Turkey.

[28] Forest Stewardship Council (FSC) (2017): Facts and figures July 2017. file:///C:/Users/gsen7/Downloads/Facts_and_Figures_2017-11-02.pdf (accessed on 13.12.2017).

[29] Gambetta, F. C., Stoian, D., Campos, J. J., Cancino, J. M., Pinelo, G. (2006): Forest Certification in Guatemala. Confronting Sustainability: Forest Certification in Developing and Transitioning Countries. - Yale School of Forestry and Environmental Studies Press, New Haven.

[30] GDF (2016): State of Turkish forest $2015 . \quad-$ https://www.ogm.gov.tr/ekutuphane/Yayinlar/T\%C3\%BCrkiye\%20Orman\%20Varl\%C4 $\% \mathrm{~B} 1 \% \mathrm{C} 4 \% 9 \mathrm{~F} \% \mathrm{C} 4 \% \mathrm{~B} 1-2016-2017 . p d f$ (accessed on 27.07.2017).

[31] General Directorate of Forestry (GDF) (2012): General Directorate of Forestry Strategic Plan 2013-2017. - Orman Genel Müdürlüğü, Ankara. https://www.ogm.gov.tr/ekutuphane/StratejikPlan/Orman\%20Genel\%20M\%C3\%BCd\% C3\%BCrl\%C3\%BC\%C4\%9F\%C3\%BC\%20Stratejik\%20Plan\%20(2013-2017).pdf (accessed on 13.07.2017).

[32] Greenacre, M. (1998): Visualization of Categorical Data. - Academic Press, San Diego, USA.

[33] Güneş Şen, S. (2015): The disposition and characteristics of precipitation at diffirient stand structures in Kastamonu-Daday region. Master Thesis, Kastamonu University Institute of Natural and Applied Sciences, Kastamonu, Turkey.

[34] Kastamonu Regional Directorate of Forestry (KRDF) (2014). Management Plan's Data of Kastamonu Regional Directorate. - Kastamonu Regional Directorate of Forestry, Kastamonu, Turkey.

[35] Kastamonu Regional Directorate of Forestry (KRDF) (2016): Data of BusinessMarketing Branch of Kastamonu Regional Directorate of Forestry. - General Directorate of Forestry, Kastamonu.

[36] Klingberg, T. (2003): Certification of forestry: a small-scale forester perspective. Small-Scale Forest Economics, Management and Policy 2(3): 409-421.

[37] Krieger, D. J. (2001): The Economic Value of Forest Ecosystem Services: A Review. The Wilderness Society, Washington D.C. https://www.sierraforestlegacy.org/Resources/Conservation/FireForestEcology/ForestEco nomics/EcosystemServices.pdf (accessed on 14. 06.2017).

[38] Lee, B. L. (1996): Correspondence analysis. LL Thurstone Psychometric Laboratory Research Memorandum. $\quad-\quad$ http://sunsite.csd.univie.ac.at/ViSta/vistaframes/pdf/chap11.pdf (accessed on 01.03.2017).

[39] LTDP (2008). Long Term Development Plan of Ilgaz Mountain National Park. Analysis Scrutiny Report. Directorate of Ilgaz Mountains National Park, Kastamonu.

[40] Nussbaum, R., Simula, M. (2005): The Forest Certification Handbook (2 ${ }^{\text {nd }}$ ed.) Earthscan, London.

[41] Orhunbilge, N. (2000): Sampling Methods and Hypothesis Testing. - Avciol Basim ve Yayın, Istanbul, Turkey.

[42] Ozinga, S. (2008): Time to measure the impacts of certification on sustainable forest management. - http://www.fao.org/docrep/008/Y5918e/Y5918e08.htm (accessed on 29.06.2017).

[43] Özdamar, K. (2002): Multivariate Statistical Analysis II (4 ${ }^{\text {th }}$ ed.). - Kaan Kitabevi, Eskişehir, Turkey. 
[44] Öztürk, S., Ayan, S. (2015): Management alternatives in national park areas: The case of Ilgaz Mountain National Park. - eco. Mont-Journal on Protected Mountain Areas Research 7: 37-44. DOI:10.1553/eco.mont-7-1.

[45] Perera, P., Vlosky, R. P. (2006): A History of Forest Certification. - Louisiana Forest Products Development Center, School of Renewable Natural Resources, LSU Ag Center, Baton Rouge. https://www.researchgate.net/publication/228396698 (accessed on 13.5.2017).

[46] Pfeifer, A. (2003): Forest Certification — what does it mean for Irish forestry? - COFORD $\begin{array}{lll}\text { Connects } & \text { Environment } & \\ \end{array}$ http://www.coford.ie/media/coford/content/publications/projectreports/cofordconnects/Ce rtification.pdf (accessed on 21.05. 2017).

[47] Pinto, L. F. G., McDermott, C. (2013): Equity and forest certification-A case study in Brazil. - Forest Policy and Economics 30: 23-29.

[48] Pratiwi, S., Wibowo, A., Giessen, L. (2015): Third-party certification of forest management in Indonesia: Analysing stakeholders' recognition and preferences. - Jurnal Manajemen Hutan Tropika 21(2): 65-75.

Rahman, L. M. (2015): Bangladesh national conservation strategy - forest resources. Ministry of Environment and Forests Government of the People's Republic of Bangladesh, Bangladesh, Pakistan. http://fd.portal.gov.bd/sites/default/files/files/fd.portal.gov.bd/notices/c3379d22_ee62_4d ec_9e29_75171074d885/4.\%20Forest\%20resources_NCS.pdf (accessed on 12.16.2017).

[49] Rametsteiner, E. (2002): The role of governments in forest certification - a normative analysis based on new institutional economics theories. - Forest Policy and Economics 4(3): 163-173.

[50] Rametsteiner, E., Simula, M. (2003): Forest certification-an instrument to promote sustainable forest management? - Journal of Environmental Management 67(1): 87-98.

[51] Serper, Ö. (2000): Applied Statistics II ( $4^{\text {th }}$ ed.). - Ezgi Kitabevi, Bursa, Turkey.

[52] Şen, G., Unal, S., Erkan Bugday, S. (2013): Illegal utilizations; before and after certified (a case study of Kastamonu Regional Directorate of Forestry). - Forest certification and protection from illegal logging. International and Russia aspect. - St. Petersburg State Forest Technical University, St. Petersburg, Russia. http://www.academia.edu/21245285/ILLEGAL_UTILISATION_BEFORE_AND_AFTE R_THE_CERTIFIED_A_CASE_STUDY_OF_KASTAMONU_REGIONAL_FOREST_ DIRECTORATE.

[53] Şenöz, İ. H. (2014): Forestry certification and importance in terms of forestry policy. Master Thesis, Istanbul University Institute of Natural and Applied Sciences, Istanbul, Turkey.

[54] Trishkina, M., Lopatina, E., Karjalainen, T. (2014): Assessment of motivation and attitudes of forest industry companies toward forest certification in northwestern Russia. - Scandinavian Journal of Forest Research 29(3): 283-293.

[55] Toksoy, D., Şen, G., Özden, S., Ayaz, H. (2008): The forestry organization and its relationship with local people in the Eastern Black Sea Region of Turkey. - New Medit (Mediterranean Journal of Economics, Agriculture and Environment) 7(4): 46-53.

[56] Tolunay, A., Başsüllü, Ç. (2015): Willingness to pay for carbon sequestration and cobenefits of forests in Turkey. - Sustainability 7(3): 3311-3337.

[57] Tolunay, A., Türkoğlu, T. (2014): Perspectives and attitudes of forest products industry companies on the chain of custody certification: a case study from Turkey. Sustainability 6(2): 857-871. DOI:10.3390/su6020857.

[58] Tolunay, A., Türkoglu, T., Elbakidze, M., Angelstam, P. (2014): Determination of the support level of local organizations in a model forest initiative: do local stakeholders have willingness to be involved in the model forest development? - Sustainability 6: 71817196. DOI:10.3390/su6107181. 
[59] Turkish Statistical Institute (TSI). (2016): Population of Kastamonu City. www.tuik.gov.tr (accessed on 21.12.2016).

[60] Uzgoren, N. (2007): Theoretical Basis of Correspondence Analysis and Comparison of Its Similarities with Regression Analysis on the Graphic. - Dumlupinar Universitesi, Sosyal Bilimler Dergisi, Sayi 18. https://birimler.dpu.edu.tr/app/views/panel/ckfinder/userfiles/17/files/DERG_/18/1 20.pdf (accessed on 01.11.2017).

[61] Vidal, N., Kozak, R., Cohen, D. (2005): Chain of custody certification: an assessment of the North American solid wood sector. - Forest Policy and Economics 7: 345-355.

[62] Yildırım, T. H. (2010). Examination of wood production-consumption relations in terms of forest policy in Turkey. - PhD Thesis, İstanbul University Institute of Natural and Applied Sciences, İstanbul.

[63] Zhao, J., Xie, D., Wang, D., Deng, H. (2011): Current status and problems in certification of sustainable forest management in China. - Environmental Management 48(6): 10861094. 